\title{
Interleukin-1 gene variants and the risk of non-syndromic microtia
}

\author{
Interlökin 1 gen varyantları ve sendromik olmayan mikrotia riski
}

\author{
Ayşe Feyda Nursal ${ }^{*}$, Mehmet Bekerecioğlu**, Berker Büyükgüral ${ }^{* * *}$, Sacide Pehlivan*** \\ * Hitit Üniversitesi, Tıp Fakültesi,Tıbbi Genetik Anabilim Dalı, Çorum \\ ${ }^{* *}$ Kahramanmaraş Sütçü Imam Üniversitesi, Tıp Fakültesi, Plastik, Rekonstrüktif ve Estetik Cerrahi Ana Bilim \\ Dalı, Kahramanmaraş \\ ***Plastik, Rekonstrüktif ve Estetik Cerrahi Uzmanı, Istanbul \\ ****Istanbul Üniversitesi, Istanbul Tıp Fakültesi, Tıbbi Biyoloji Ana Bilim Dalı, Istanbul
}

\begin{abstract}
Purpose: Microtia is a congenital anomaly, manifested by a small and disfigured auricle. Interleukin (IL) 1 is an important mediator of inflammation and cartilage destruction, This study is aimed at investigating association of IL-1A (-889) and IL-1B (-511) variants in a Turkish patient population with microtia.

Meterials and Methods: Nineteen patients diagnosed with microtia and 40 healthy controls were enrolled to the study. The IL-1A (-889) and IL-1B (-511) variants were evaluated using the polymerase chain reaction-restriction fragment length polymorphism (PCR-RFLP) method. For statistical analysis, SPSS version 22.0 was used.

Results: The genotype distribution of the IL-1A (-889) variant was statistically different between the cases and the control group. IL-1A -889 CC genotype was lower in microtia cases while TT genotype was more prevalent in microtia cases, respectively $(p=0.008, p=0.008)$. High difference was also observed when the patient group and the control group were compared according to IL-1 (-889) CT+TT ( $p=0.003)$. IL-1A (-889) C allele was lower in microtia patients and T allele was higher in patients $(p=0.005)$. The allele frequency and genotype distribution of IL-1B (-511) CT variant did not show any statistically difference between patients and controls $(p>0.05)$.

Conclusion: To our knowledge, for the first time in the literature we have demonstrated a significant association of the IL-1A (-889) functional variant with microtia in a Turkish cohort.
\end{abstract}

Pam Med J 2018;11(2):89-94

Key words:Microtia, interleukin-1A, interleukin-1B, variant

Özet

Amaç:Mikrotia küçük ve şekil bozukluğu olan kulak kepçesi ile görülen kongenital bir anomalidir. İnterlökin (IL) 1 enflamasyon ve kıkırdak harabiyeti için önemli bir düzenleyicidir. Bu çalışma Türk mikrotia hastalarında IL-1A (-889) ve IL-1B (-511) varyantlarının ilişkisini değerlendirmeyi amaçlamıştır.

Gereç ve Yöntem: Çalışmaya mikrotia tanılı 19 hasta ve 40 sağılılı kontrol dahil edilmiştir. IL-1A (-889) ve IL-1B (-511) varyantları polimeraz zincir reaksiyonu (PZR)- sınırlayıcı parça uzunluk polimorfizm (RFLP) yöntemi ile incelenmiştir. İstatistik analiz için, SPSS 22.0 versiyonu kullanılmıştır.

Bulgular:IL-1A (-889) varyant genotip dağılımı hastalar ve kontrol grubu arasında istatistiksel olarak farklıydı. IL-1A -889 TT genotipi mikrotia hastalarında daha yaygınken, CC genotipi mikrotia hastalarında daha azdı, sırasıyla ( $p=0.008, p=0.008)$. Hasta ve kontrol grupları IL-1 (-889) CT+TT durumuna göre karşılaştırıldığında büyük fark saptandı $(p=0.003)$. IL-1A (-889) C alleli mikrotia hastalarında azdı ve $T$ alleli hastalarda çoktu $(p=0.005)$. IL-1B (-511) CT varyant genotip ve allel dağılımı hastalar ve kontrol arasında herhangi istatistiksel fark göstermedi $(p>0.05)$.

Sonuç:Bildiğimiz kadarıyla literatürde ilk olarak, IL-1A (-889) fonksiyonel varyantın Türk topluluğunda mikrotia ile önemli ilişkisi olduğunu gösterdik.

Pam Tıp Derg 2018;11(2):89-94

Anahtar sözcükler: Microtia, interlökin-1A, interlökin-1B, varyant

Ayşe Feyda Nursal

Yazışma Adresi:Hitit Üniversitesi Tıp Fakültesi Tıbbi Genetik Anabilim Dalı, Çorum.

e-mail: feydanursal@hotmail.com 


\section{Introduction}

Microtia (MIM 600674, MIM 251800) is a congenital malformation that is frequently accompanied with aural atresia. Its incidence ranges between 0.83 and 4.34 per 10,000 deliveries, and it is more common among the males and Asian population [1]. Diagnosis of microtia covers a variety of phenotypes, ranging from "mild structural malformations to complete agenesis of the ear," however even minor cases may cause psychological distress because of the disfigurement and its psychosocial impact [1]. Microtia may exist as an isolated condition, or as part of a group of anomalies or a syndrome. Vertebral anomalies, macrostomia, oral clefts, facial asymmetry, renal malformations, cardiac defects, microphthalmia, holoprosencephaly, and polydactyly are among the most common anomalies seen with microtia [1]. The etiology of microtia-anotia remains unclear. Although environmental factors may play significant role, genetic causes are also involved [2].

Early pregnancy in mammals necessitates complex and highly coordinated cellular and molecular mechanisms taking place in the endometrium and the conception product. Interleukins (ILs) constitute a group of proinflammatory cytokines that plays an important role in mammalian reproduction. The IL-1 gene, consisting of IL-1A (IL1A), IL1B (IL1B), and IL-1RN (IL1RA), is found on the chromosome $2 q 14-21$ [3]. IL-1 is a major regulator of inflammation and immune reactions. Both $\mathrm{IL}-1 \mathrm{~A}$ and $\mathrm{IL}-1 \mathrm{~B}$ initiate inflammation, but more significantly, they stimulate the expression of proinflammatory genes, including cyclooxygenase type 2 , inducible nitric oxide synthase, and some other cytokines. The IL-1 system is closely associated with implantation [4]. Furthermore, the in vitro activation of cultured chondrocytes by IL-1 is linked with significant changes in the expression of numerous genes that are involved in the cartilage breakdown [5]. The IL-1A gene manifests polymorphisms at several loci. A single base substitution (C/T) at position (-889) (rs1800587) is linked with elevated cytokine synthesis [6]. IL-1B gene has a CT bi-allelic polymorphism (rs16944) in the promoter region at position -511 [7]. The variant allele at this locus $\mathrm{T}$ has been reported to be related to several inflammatory disorders and individuals carrying IL-1B (-511) T allele have higher levels of IL-1B [8].
Therefore, this study is aimed at investigating possible association of IL-1A (-889) and IL-1B $(-511)$ variants in Turkish microtia patients.

\section{Material and Methods}

\section{Study population}

The study group consisted of 19 cases with microtia and 40 healthy controls. The participants, who admitted to Department of Plastic, Reconstructive and Aesthetic Surgery were diagnosed with microtia. The healthy control group was balanced according to age, sex, and consisted of outpatients that did not have any congenital malformations. An accurate and detailed family history was obtained for each patient. Both the study group and the control group were of Turkish origin, from the same region of Turkey. Informed written consent was obtained from all patients and subjects before enrollment to the study, according to the ethical guidelines of the 2008 Declaration of Helsinki and the investigation was approved by the Institutional Ethical Committee.

\section{Genotype determination}

Blood samples from all participants were collected in tubes containing ethylene diamine tetra acetic acid. Genomic DNA was extracted from peripheral whole blood according to established protocol [9]. IL-1A and IL-1B gene variants were determined by polymerase chain reaction $(P C R)$ followed by restriction fragment length polymorphisms (RFLP) IL-1A (-889) variant was determined using primers 5'-AAG CTT GTT CTA CCA CCT GAA CTA GGC3' and 5'-TTA CATATG AGC CTT CCA TG-3' previously described [10]. Amplified products digested Ncol enzyme. The IL-1B (-511) variant was determined by PCR using the following primers 5' GTTGTCATCAGACTTTGACC 3' and 5' TTCAGTTCATATGGACCAGA 3' [11]. PCR products were digested by restriction endonuclease Aval (MBI Fermentas) at $37^{\circ} \mathrm{C}$ for overnight. The PCR products were seperated on a $2 \%$ agarose gel and DNA was visualized by ethidium bromide staining.

\section{Statistical analysis}

All statistical analyses were performed using computer SPSS Statistical Program Version 22.0 and OpenEpi info 2.2 software package program. Continuous data were given as mean $\pm S D$ (standard deviation) and (min/max). 
$x^{2}$ test was used to significance of differences in the allele frequency and genotype distribution between the two study groups. Odds ratio (OR) and $95 \%$ confidence intervals (Cls) were calculated. The Hardy-Weinberg Equilibrium (HWE) was determined using a software analysis [12]. $p$ value $p<0.05$ was considered statistically significant.

\section{Results}

A total number of 59 subjects from a Turkish population were recruited (19 patients with microtia, 40 controls) in this study. The frequency of genotypes and alleles of IL-1A -899 variant in patients with microtia and controls are shown in Table 1. The overall distribution of the IL-1A (-889) variant was $36.8 \% \mathrm{CC}, 36.8 \% \mathrm{CT}$, and $26.4 \%$ TT in microtia cases, respectively. Among the controls, frequencies for the $\mathrm{CC}$, CT, TT genotypes of IL-1A (-889) variant were $65 \%, 30 \%$, and $5 \%$, respectively. The genotype distribution of the IL-1A (-889) variant was statistically different between the cases and the control group. IL-1A (-889) CC genotype was lower in cases while TT genotype was more prevalent in cases, respectively $(p=0.008$, $p=0.008$ ). High difference was also observed when the patients and the controls were compared according to CT+TT $(p=0.003)$. There was a significant difference for allele frequency of the IL-1A (-899) variant between the groups. The frequency of the IL-1A (-889) $C$ allele was found to be significantly lower in patients compared to controls while IL-1A (-889) T allele was higher in patients $(p=0.005)$.

The genotype and allele frequencies of IL$1 \mathrm{~B}(-511)$ variant among the microtia cases and controls are shown in Table 2. For the IL-1B (-511) CT variant, the genotype distribution for microtia cases and control groups were as follows: $47.4 \%$ were CC, $31.6 \%$ had the heterozygote CT genotype, and $21 \%$ were homozygote for TT in the microtia cases group compared with $47.5 \%$ who were CC, $42.5 \%$ with the CT genotype, and $10 \%$ who had TT in the control group. The genotype and allele

Table 1. Genotype distribution and allele frequencies of IL-1A variant in cases and controls

\begin{tabular}{lccc}
\hline IL-1A (-889) & Control group $\mathbf{n ~ ( \% ) ~}$ & Microtia group $\mathbf{n ~ ( \% ) ~}$ & $\mathbf{p}$ \\
\hline Genotype & & & \\
CC & $26(65)$ & $7(36.8)$ & 0.008 \\
CT & $12(30)$ & $7(36.8)$ & 0.166 \\
TT & $2(5)$ & $5(26.4)$ & 0.008 \\
CC+CT & $38(95)$ & $14(73.7)$ & 0.003 \\
Allele & & & \\
C & $64(80)$ & $21(55.3)$ & 0.005 \\
T & $16(20)$ & $17(44.7)$ & \\
\hline HWEp & $\mathbf{0 . 6 9 2}$ & $\mathbf{0 . 2 6 6}$ & \\
\hline IL-1A: Interleukin-1A, HWEp: Hardy Weinberg Equilibrium & &
\end{tabular}

Table 2. Genotype distribution and allele frequencies of IL-1B variant in cases and controls

\begin{tabular}{|c|c|c|c|}
\hline IL-1B (-511) & Control group n (\%) & Microtia group n (\%) & $p$ \\
\hline \multicolumn{4}{|l|}{ Genotype } \\
\hline $\mathrm{CC}$ & $19(47.5)$ & $9(47.4)$ & $>0.05$ \\
\hline Ст & $17(42.5)$ & $6(31.6)$ & $>0.05$ \\
\hline TT & $4(10)$ & $4(21)$ & $>0.05$ \\
\hline \multicolumn{4}{|l|}{ Allele } \\
\hline$T$ & $55(68.8)$ & $24(63.2)$ & $>0.05$ \\
\hline C & $25(31.2)$ & $14(36.8)$ & \\
\hline HWEp & 0.944 & 0.161 & \\
\hline
\end{tabular}


distribution of IL-1B (-511) CT variant did not show any statistically difference between patients and controls $(p>0.05)$. When the patients and the controls were compared in terms of HWE, deviation were not observed in both IL-1A (-889) and IL-1B (-511) variants.

\section{Discussion}

Microtia is an uncommon congenital defect manifested by the abnormal development of the outer ear leading to a malformed auricle. Microtia can exist on both sides, however 77$93 \%$ of the patients have unilateral involvement [13]. The right ear is affected in about $60 \%$ of the patients with unilateral microtia [13] (Forrester $\mathrm{MB})$. Etiology of microtia and the associated syndromes are unclear, however genetic and environmental factors are believed to be involved. Several familial cases with Mendelian inheritance have been reported [14].

Rates of familial cases among microtia patients differ widely, ranging between 3 and $34 \%$ [14]. Hereditary forms of microtia with autosomal recessive or dominant inheritance with variable expression and incomplete penetrance have all been reported [14]. Familial cases with certain clinical characteristics such as microtia, without any known syndrome have also been reported. Animal studies have found a number of genes linked with microtia, and demonstrated some signaling pathways, such as BMP, WNT, FGF and retinoic acid, that involve in development of outer ear [1].

Normal growth and implantation of the early embryo is a crucial developmental process that involves embryonic-maternal signaling. The exact mechanisms and sequence of these signaling events remain unclear. Cytokines were reported to play important role in embryonic development. These molecules are small, multifunctional glycoproteins, that act as biological mediators, regulating several functions during embryo-maternal interactions [15]. It has been suggested that cytokines play a role in the regulation of pre-implantation embryo development. The cytokine levels in pregnant uterus differs from the non-pregnant uterus.

IL-1 is a major modulator of inflammation, with pleiotropic impacts on many cells and signaling pathways. IL-1 is involved in the modulation of placental and endometrial function during gestation. In humans, IL-1 is synthesized in endometrium during the late secretory phase of the menstrual cycle and during gestation [16]. Furthermore, IL-1 also regulates immunologic cytokine synthesis in the placenta. In the mouse, $\mathrm{IL}-1$ is expressed in endometrium and peak levels are observed during implantation. Orsi et al. measured 18 different cytokines during the estrous cycle, gestation and post-partum period in mice. They found that most cytokines, such as IL-1A and IL-1B were detected throughout all phases [17].

IL-1 has several impacts in chondrocytes such as a significant decrease in the expression of anabolic genes like aggrecan and collagen type /I [18], up-regulation of some catabolic genes like matrix degrading proteases (matrix metalloproteinase-1, -3, -13, and ADAMTS-4) [19], and stimulation of intercellular mediators including leukemia inhibitory factor and IL-6 [20]. IL-1 induces a net loss of proteoglycan from both articular and nasal cartilage in organ culture by forcing the chondrocytes to elevate the rate of proteoglycan degradation and lower the rate of proteoglycan production [21]. Thus, $\mathrm{IL}-1$ may be a crucial regulator of cartilage loss in arthritis. IL-1A (-889) and IL-1B (-511) variants locate in the promoter region of the genes, and they have been proved to affect the expression level of these genes [22,23].

Therefore, in present study, we hypothesized whether the possible association between IL1A (-889)/ IL-1B (-511) variants and microtia susceptibility in a Turkish cohort. To our knowledge, this is the first study to investigate the association between $\mathrm{IL}-1$ variants and microtia in a Turkish cohort. We found that IL$1 \mathrm{~A}(-889)$ variant is significantly different in the microtia cases and the controls. IL-1A (-889) CC genotype was lower in microtia cases while TT genotype was more prevalent in patients, respectively $(p=0.008, p=0.008)$. This is thought that IL-1A CC genotype has a protective role for microtia. Also IL-1A TT genotype may play a role for susceptibility to microtia. Additionally, high difference was observed when the patients and the controls were compared according to CT+TT $(p=0.003)$. Also, IL-1A allele frequencies were significantly different between cases and controls. IL-1A (-889) C allele was lower in patient group but IL-1A (-889) T allele was higher in patients $(p=0.005)$. However, the allele frequency and genotype distribution 
of IL-1B (-511) CT variant did not show any statistically difference between patients and controls $(p>0.05)$.

In conclusion, we reported the first association to our knowledge between IL-1A gene variant and microtia in a Turkish cohort. The present study revealed that IL-1A variant was associated with a susceptibility to microtia. The limitation of this study was the small number of patients and therefore reduced the statistical power. Further investigations with larger populations are needed to confirm this result.

\section{Conflict of interest}

The authors declare that they have no conflicts of interest.

\section{References}

1. Luquetti DV, Heike CL, Hing AV, Cunningham ML, Cox TC. Microtia: Epidemiology and genetics. Am J Med Genet A 2012;158A:124-139.

2. Cremers CW. Meatal atresia and hearing loss. Autosomal dominant and autosomal recessive inheritance. Int J Pediatr Otorhinolaryngol 1985;8:211213.

3. Vishnoi M, Pandey SN, Choudhuri G, Mittal B. IL-1 gene polymorphisms and genetic susceptibility of gallbladder cancer in a north Indian population. Cancer Genet Cytogenet 2008;186:63-68.

4. Kruessel JS, Huang HY, Wen Y, Kloodt AR, Bielfeld $\mathrm{P}$, Polan ML. Different pattern of interleukin-1 beta(IL-1 beta), interleukin-1 receptor antagonist- (IL-1ra) and interleukin-1 receptor type I- (IL-1R tl) mRNAexpression in single preimplantation mouse embryos at various developmental stages. J Reprod Immunol 1997;34:103-120.

5. Cortial D, Gouttenoire J, Rousseau CF, et al. Activation by IL-1 of bovine articular chondrocytes in culture within a $3 \mathrm{D}$ collagen-based scaffold. An in vitro model to address the effect of compounds with therapeutic potential in osteoarthritis. Osteoarthritis Cartilage 2006;14:631-640.

6. Haroon J, Hussain S, Javed Q. Heritability of IL1A Gene Promoter Polymorphism in Patients With Coronary Artery Disease: A Trio-Family Study. Lab Med 2015;46:20-25.

7. di Giovine FS, Takhsh E, Blakemore AI, Duff GW. Single base polymorphism at -511 in the human interleukin-1 beta gene (IL1 beta). Hum Mol Genet 1992;1:450.
8. Achyut BR, Srivastava A, Bhattacharya S, Mittal B. Genetic association of interleukin-1beta (-511C/T) and interleukin-1 receptor antagonist (86 bp repeat) polymorphisms with Type 2 diabetes mellitus in North Indians. Clin Chim Acta 2007;377:163-169.

9. Miller SA, Dykes DD, Polesky HF. A simple salting out procedure for extracting DNA from human nucleated cells. Nucleic Acids Res 1988;16:1215.

10. Maria de Freitas, $N$ Imbronito AV, Neves AC, Nunes FD, Pustiglioni FE, Lotufo RF. Analysis of IL-1A(-889) and TNFA(-308) gene polymorphism in Brazilian patients with generalized aggressive periodontitis. Eur Cytokine Netw 2007;18:142-147.

11. Bioque G, Crusius JB, Koutroubakis I, et al. Allelic polymorphism in IL-1 beta and IL-1 receptor antagonist (IL-1Ra) genes in inflammatory bowel disease. Clin Exp Immunol 1995;102:379-383.

12. http://ihg2.helmholtz-muenchen.de/cgi-bin/hw/hwa1. pl.(Accessed July 29,2017)

13. Forrester MB, Merz RD. Descriptive epidemiology of anotia and microtia, Hawaii, 1986-2002. Congenit Anom (Kyoto) 2005;45:119-124.

14. Alasti F, Van Camp G. Genetics of microtia and associated syndromes. J Med Genet 2009;46:361-369.

15. Singh M, Chaudhry $P$, Asselin E. Bridging endometrial receptivity and implantation: network of hormones, cytokines, and growth factors. J Endocrinol 2011;210:514.

16. Kauma $S$, Matt $D$, Strom $S$, Eierman $D$, Turner $T$. Interleukin-Ip (IL-Ib), human leukocyte antigen HLA$\mathrm{DRn}$, and transforming growth factor-b (TGF-b) expression in endometrium, placenta and placental membranes. Am J Obstet Gynecol 1990;163:14301437.

17. Orsi NM. Cytokine networks in the establishment and maintenance of pregnancy. Hum Fertil (Camb) 2008;11:222-230.

18. Goldring MB, Birkhead JR, Sandell LJ, Kimura T, Krane SM. Interleukin 1 suppresses expression of cartilagespecific types II and IX collagens and increases types I and III collagens in human chondrocytes. J Clin Invest 1988;82:2026-2037

19. Richardson DW, Dodge GR. Effects of interleukin$1 \beta$ and tumor necrosis factor- $\alpha$ on expression of matrix-related genes by cultured equine articular chondrocytes. Am J Vet Res 2000;61:624-630.

20. Henrotin YE, DeGroove DD, Labasse AH, et al. Effects of exogenous IL-1, TNF- $\alpha, \mathrm{IL}-6, \mathrm{IL}-8$ and LIF on cytokine production by human articular chondrocytes. Osteoarthritis Cartilage 1996;4:163-173. 
21. Arner EC, Pratta MA. Modulation of interleukin1-induced alterations in cartilage proteoglycan metabolism by activation of protein kinase C. Arthritis Rheum 1991;34:1006-1013.

22. Ghasemi M, Kashani E, Fayyaz A, Attar M, Shahbazi M. Interleukin-1 alpha variation is associated with the risk of developing preeclampsia. Eur J Obstet Gynecol Reprod Biol 2015;193:75-78.

23. Sun $X$, Cai H, Li Z, et al. Association between IL-1 polymorphisms and gastritis risk: A meta-analysis. Medicine (Baltimore) 2017;96:e6001. 